\title{
How the nitrogen fertilization dose affects the biochemical composition and net mineralization of the artichoke residues
}

\author{
E.K. Mahmoud* and N.K. Abd EL-Kader \\ Department of soil and water science, Faculty of Agriculture, Tanta University, Egypt. \\ "Corresponding author:dr_3esawe@yahoo.com
}

\begin{abstract}
In Egypt, recycling of vegetable and crop residues is improving of environmental and efficiency of nitrogen use. In this study, artichoke (Cynara cardunculus L.) plants have been grown in field for nine months at three rates of nitrogen fertilization: 0 (N0), 250 (N250), 500 (N500) $\mathrm{kg} \mathrm{ha}^{-1}$. The aims of this study are to assess effect of nitrogen fertilization of previous treatments on the chemical composition and mineralization of the artichoke. The results showed that the artichoke residues of the treatment N500 contained higher amounts of lignin, cellulose, hemicellulose and soluble $\mathrm{C}$ at $100^{\circ} \mathrm{C}$ and a lower soluble fraction Van Soest than N0 and N250 treatments. Artichoke residues contained 129.3, 89.2 and $57.4 \mathrm{~kg} \mathrm{~N}$ ha $^{-1}$ for N500, $\mathrm{N} 250$ and N0, respectively. Carbon of artichoke residues was mineralized above $60 \%$ at 50 days in the incubation experiment, and then slowly $\mathrm{CO}_{2}$ release. Net $\mathrm{N}$ immobilization was observed during the first days of incubation in N0 and N250 treatments. While, the N500 treatment was mineralized immediately. The study demonstrated that the net $\mathrm{N}$ mineralization ranged from $38.26 \mathrm{mg} \mathrm{N} \mathrm{kg}^{-1}$ dry soil for the control soil without residues to $56.30 \mathrm{mg} \mathrm{N} \mathrm{kg}^{-1}$ dry soil for the soil treated with artichoke residues N500. These results could lead to greater efficiency of $\mathrm{N}$ use in rotations through return of vegetable residues, and alternative methods to improve the efficiency of vegetable residues disposal.
\end{abstract}

Keywords: Artichoke residues, Incubation, Mineralization, Fertilization, Disposal, Rotations. 


\section{Introduction}

Vegetable and crop residues become a very serious problem in Egypt lately that is because of the huge production of residues about 24 million ton year ${ }^{-1}$ (ElShemy and Aly, 1997). The farmers start to burn vegetable and crop residues causing the black cloud and severe pollution in Egyptian atmosphere. High fertilizer inputs and the low crop recoveries of fertilizer nutrients (usually $<10 \%$ in the case of $\mathrm{N}$ ) lead to marked deterioration in soil and groundwater quality and the systems are clearly unsustainable (Zhu et al., 2005).

Vegetable production is often characterized by an excessive use of $\mathrm{N}$ fertilization e.g. potato, artichoke and cauliflower, resulting in large mineral $\mathrm{N}$ residues in the soil and large amounts of crop residues rich in nitrogen at the harvest which stimulates the soil microbial metabolism and soil enzymes (De Neve and Hofman, 2002; Rahn et al., 1992).Their biological decomposition depends on the degradation rate of a wide range of $\mathrm{C}$ compounds present in the sample (carbohydrates, amino acids, fatty acids, lignin, etc.), as well as on their nutrient content. Then the amount of $\mathrm{CO}_{2}-\mathrm{C}$ released from organic wastes in soil has been shown to depend on the material used and on their biochemical composition (Ajwa and Tabatabai, 1994). Mineralization processes are significant, particularly in soils affected by the long term cultivation and different cropping practices (Qualls and Richardson, 2000). Soil management and cropping practices are known to modify factors that affect most biological processes in the soil. soil tillage and crop residue management affected microbial population, activity, decrease or increase $\mathrm{C}$ and $\mathrm{N}$ dynamics and biomass (Islam and Weil, 2000). During mineralization of these crop residues, additional mineral $\mathrm{N}$ is released into the soil, resulting in large nitrate residues in the soil during the autumn and winter and serious problems with respect to nitrate leaching. Cauliflower residues as example contained from 80 to $120 \mathrm{~kg} \mathrm{~N}^{-1}$
(Wehrmann and Scharpf 1989; Everaarts et al. 1996). Several studies have reported increased soil mineral N content following harvesting of plantation vegetables (Rahn et al., 1992; De Neve and Hofman, 1998).

The nitrogen fertilization has an effect on the total nitrogen and nitrate content of vegetable residues, (Lisiewska and Kmiecik, 1996; Alt et al., 2000). The knowledge of the nitrogen availability of these residues makes it possible to improve nitrogen use efficiency and to reduce the pressure agricultural on the environmental. Not all nitrogen taken up by crops ends up in harvestable produce. Of the total amount of nitrogen taken up by, e.g., cauliflower only about $50 \%$ is removed from the field with the product (Everaarts et al. 1996). The other $50 \%$ remains on the field in the crop residues. Crop residues of spinach and celeriac contain 25-60 kg N hä (Wehrmann and Scharpf 1989),

Artichoke (Cynara cardunculus L.) is a perennial rosette plant grown throughout the world for its large, fleshy heads. Most of its cultivation area is in the Mediterranean countries (Azza et al., 2010). Mineralization of artichoke residues (which over 65\%) was not be studied until now. So, the aims of this study were to assess effect of nitrogen fertilization on the biochemical characteristics of the artichoke and nitrogen and carbon mineralization from artichoke residues.

\section{Materials and Methods}

\subsection{Soil used and Artichoke experiments}

The composite soil used $(0-20 \mathrm{~cm})$ for the incubation experiments was a clay loam. Its main characteristics were $40.67 \%$ silt, $10.69 \%$ sand, $48.39 \%$ clay, 1.12 $\%$ organic matter, $9.74 \% \mathrm{CaCO}_{3}, 0.49 \mathrm{~g}$ total $\mathrm{N} \mathrm{kg}^{-1}$, $0.54 \mathrm{~g}$ total $\mathrm{P} \mathrm{kg}^{-1}$ on a dry weight basis, $7.95 \mathrm{pH}$ and EC of $3.85 \mathrm{dS}^{-1}$ (soil saturated extract). These soil characteristics were determined according to Page 
(1982). The soil was taken after harvest artichoke to use in the incubation experiments for 180 days after leaving in field for one year without cultivation and disposal of weeds. Artichoke plants were grown in field for nine months during 2010/2011 seasons in Sedi Ghazy, Baharia governorate, Egypt. Three N fertilization rates were applied to artichoke plants: (1) a without $\mathrm{N}$ fertilization (N0), (2) a with $250 \mathrm{~N} \mathrm{~kg}^{-1}$ fertilization (N250), (3) a with $500 \mathrm{~N} \mathrm{~kg}^{-1}$ fertilization (N500) $\mathrm{kg} \mathrm{ha}^{-1}$ that used by farmers. Each one was designed as a randomized complete block with three replications. The experimental unit included 5 ridges $40 \mathrm{~cm}$ in width and $4.0 \mathrm{~m}$ length, occupying an area of $8.0 \mathrm{~m}^{2}$. Nitrogen was given as urea $(46.5 \% \mathrm{~N})$ in equal portions, after one and two moths from planting. The stems, leaves and residues of tuber taken from these plants (10 plants for each treatment) after harvest were separated carefully. The mixture of artichoke residues included stems, leaves and residues of tuber that it uses in the mineralization experiment for 180 days after drying at $45^{\circ} \mathrm{C}$ with added for each treatment at the rate of $2.0 \mathrm{~g}$ dry matter $\mathrm{kg}^{-1}$ dry soil. Ash content of the $10 \mathrm{~g}$ of compost sample was determined by heating a muffle oven at $550^{\circ} \mathrm{C}$ for $8 \mathrm{~h}$, and organic matter was calculated as the difference between ash and dry weight. Fifty percent of the organic matter was considered to be carbon (AFNOR 1991).

\subsection{Carbon mineralization}

Carbon mineralization was studied in a laboratory incubation experiment at constant temperature and moisture. The mixture of the previous three treatments was one incorporated with $600 \mathrm{~g}$ dry soil and placed into 1500-ml capacity jars and mixed with double distilled water using 2:1 of water-soil ratio. A test tube ( $6 \mathrm{~cm}$ length, $2.5 \mathrm{~cm}$ diameter) containing $10 \mathrm{ml}$ of $0.5 \mathrm{M} \mathrm{NaOH}$ was placed in each jar. The jars were sealed with rubber corks and incubated at $28 \pm 1$
${ }^{\circ} \mathrm{C}$. The evolved $\mathrm{CO}_{2}$ trapped in $\mathrm{NaOH}$ and the excess alkali was titrated with $0.5 \mathrm{M} \mathrm{HCl}$ after precipitating the carbonate with $30 \% \mathrm{BaCl}_{2}$ solution. The cumulative $\mathrm{C}$ mineralization was calculated as the difference between $\mathrm{CO}_{2}$ evolved from the soil containing residues and $\mathrm{CO}_{2}$ evolved from the soil without residues.

\section{3. $N$ mineralization}

$20 \mathrm{~g}$ fresh soil was taken at different days for each treatment and $\mathrm{KCl}(2 \mathrm{~N})$ was added, shaking for $1 \mathrm{~h}$ and filtering. Inorganic nitrogen $\left(\mathrm{NH}_{4}^{+}\right.$plus $\left.\mathrm{NO}_{3}^{-}\right)$in the extracts was analyzed using the steam-distillation method (Bremner and Mulvaney, 1982). A separated set of soils was also extracted at the beginning of incubation to determine initial levels of inorganic N. Nitrogen mineralization was determined by subtracting initial inorganic $\mathrm{N}$ values from those after 180 days of incubation (Keeney and Nelson, 1982).

\subsection{Chemical composition of artichoke residues}

The dried residues were fractionated using a modification of the method proposed by Van Soest (1963). Soluble compounds (SOLVS) were separated from neutral detergent fiber (NDF) by extraction with hot water $\left(100^{\circ} \mathrm{C}\right)$ for $30 \mathrm{~min}$. followed by extraction with neutral detergent $\left(100^{\circ} \mathrm{C}\right)$ for $60 \mathrm{~min}$. The acid detergent fiber (ADF) and acid detergent lignin (ADL) fractions were then obtained as described in the original publications by Van Soest.

\section{Results}

\subsection{Effect of nitrogen fertilization on the chemical composition of artichoke residues and nitrogen uptake}

Table 1 presents effect of nitrogen fertilization on the chemical composition of the mixture artichoke resi- 
dues. The artichoke residues of the treatment N500 contained higher amounts of lignin, cellulose, hemicellulose and soluble $\mathrm{C}$ at $100^{\circ} \mathrm{C}$ and a lower soluble fraction Van Soest than N0 and N250 treatments. Nitrogen concentration of the mixture artichoke residues in the soil treated with N500 was higher than the other treatments, resulting in a lower $\mathrm{C}: \mathrm{N}$ ratio. The total dry matter (DM) yield of artichoke was increased with increasing $\mathrm{N}$ application. The amount of total dry matter of artichoke residues was 5.45, 4.43 and $4.05 \mathrm{t} \mathrm{ha}^{-1}$, for N500, N250 and N0 treatments, respectively, corresponded with $21.3640 .7,35.2$ and $36.2 \%$ of total dry matter. Total $\mathrm{N}$ uptake of artichoke plants increased with increasing $\mathrm{N}$ application (Figure 1). Artichoke residues contained 129.3, 89.2 and 57.4 $\mathrm{kg} \mathrm{N} \mathrm{ha}{ }^{-1}$ for N500, N250 and N0, respectively. The amount of $\mathrm{N}$ in the residues was about $35 \pm 1.8 \%$ of total $\mathrm{N}$ uptake.

Table 1. Chemical composition of the mixture artichoke residues based on dry matter and dry matter of artichoke. Values are means \pm standard error $(n=3)$.

\begin{tabular}{lcccc}
\hline Composition & Units & AN0 & AN250 & AN500 \\
\hline Soluble $100^{\circ} \mathrm{C}(\% \mathrm{C})$ & & $45.9 \pm 2.4$ & $52.6 \pm 1.89$ & $62.6 \pm 3.6$ \\
Soluble Van Soest & & $73.7 \pm 3.6$ & $70.4 \pm 2.8$ & $58.1 \pm 2.8$ \\
Hemicellulose & $\%$ & $9.5 \pm 0.7$ & $10.0 \pm 1.02$ & $13.8 \pm 1.7$ \\
Cellulose & $\%$ & $15.5 \pm 1.09$ & $17.8 \pm 1.02$ & $23.6 \pm 1.8$ \\
Lignin & $\%$ & $1.3 \pm 0.05$ & $1.8 \pm 0.06$ & $4.5 \pm 1.02$ \\
$\mathrm{C}$ & $\mathrm{g} \mathrm{kg}^{-1}$ & $436 \pm 11.5$ & $451 \pm 15.3$ & $463 \pm 16.2$ \\
$\mathrm{TN}$ & $\mathrm{g} \mathrm{kg}^{-1}$ & $14.3 \pm 1.7$ & $18.9 \pm 1.4$ & $30.7 \pm 1.6$ \\
$\mathrm{C}: \mathrm{N}$ ratio & $\mathrm{g} \mathrm{kg}^{-1}$ & $30.5 \pm 1.1$ & $23.9 \pm 1.2$ & $15.1 \pm 1.1$ \\
DM yield of artichoke & $\mathrm{t} \mathrm{ha}^{-1}$ & $14.3 \pm 1.02$ & $12.6 \pm 1.1$ & $13.4 \pm 0.9$ \\
DM residues & $\mathrm{t} \mathrm{ha}^{-1}$ & $4.05 \pm 0.9$ & $4.43 \pm 1.02$ & $5.45 \pm 1.4$ \\
\hline
\end{tabular}

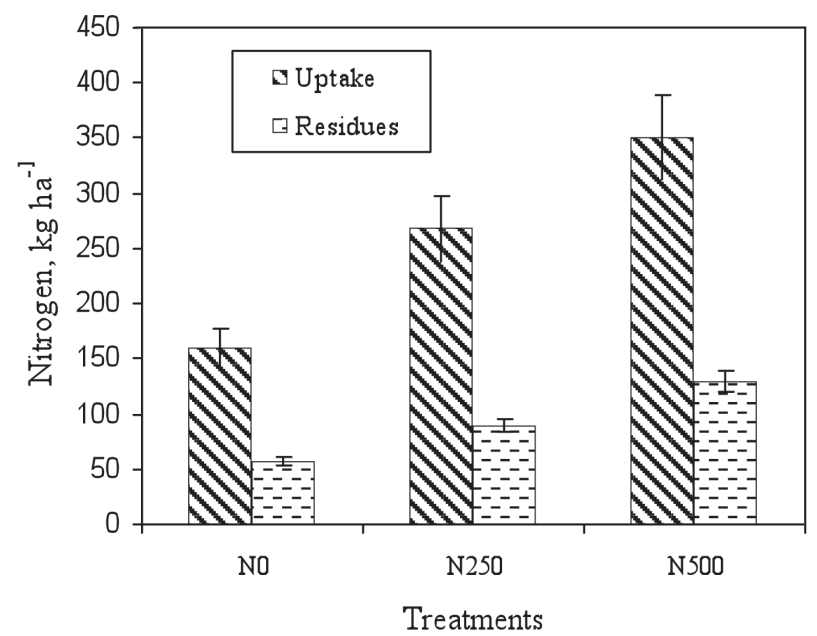

Figure 1. Effect of nitrogen application on the $\mathrm{N}$ total uptake and $\mathrm{N}$ in the residues of artichoke. Vertical bars represent + S.E.M. 
3.2. Effect of nitrogen fertilization on the carbon and nitrogen mineralization

\subsubsection{Carbon}

In this study, the effect of $\mathrm{N}$ fertilization on the amount of cumulative carbon as $\mathrm{CO}_{2}$ released during specific time-intervals from each treatment is shown in (Figure 2). In the all treatments, the amount of $\mathrm{C}-\mathrm{CO}_{2}$ initially released rapidly during the first 50 days, where more than $60 \%$ of $\mathrm{C}$ initially brought by the residues was lost in the form of $\mathrm{C}-\mathrm{CO}_{2}$. After that, the amount of $\mathrm{C}-\mathrm{CO}_{2}$ continued to increase less rapidly till 120 days, and increased again to 986,904 and $810 \mathrm{mg} \mathrm{C} \mathrm{kg}^{-1}$ of dry soil by the end of the incubation period for the N500, N250 and N0 treatments, respectively. Significant difference was observed between the three treatments at 180 days with the threshold $(p>0.05)$.

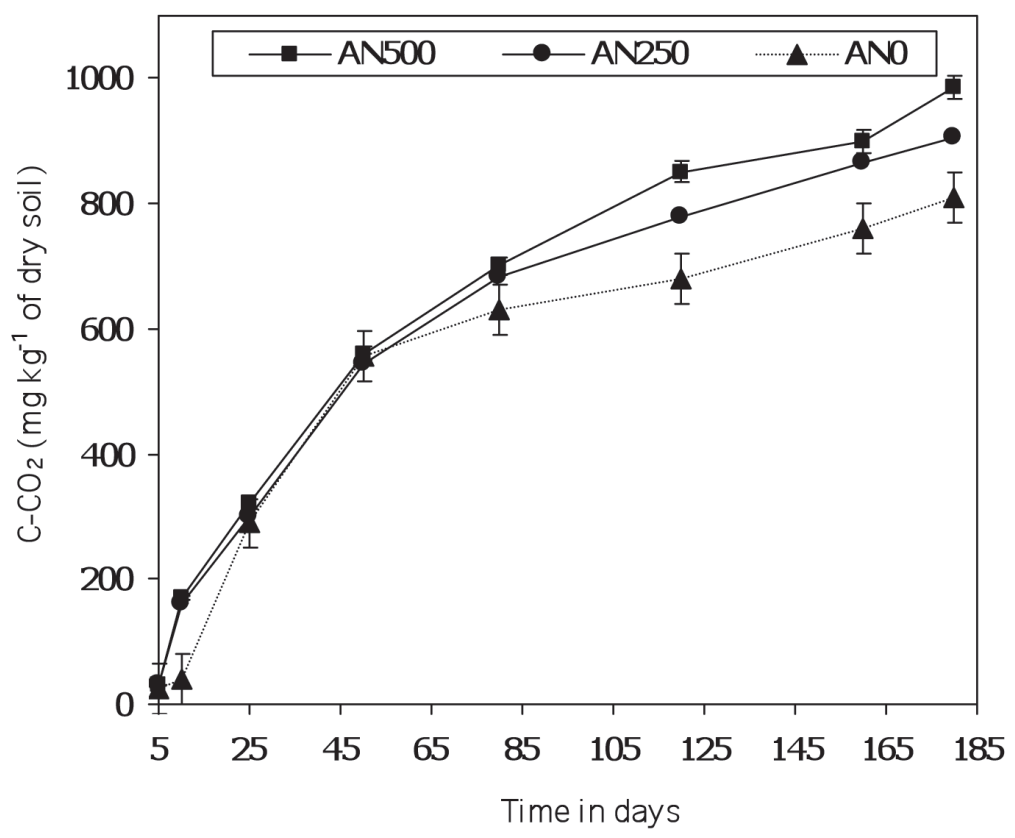

Figure 2. Effect of nitrogen fertilization on the cumulative $\mathrm{CO}_{2}-\mathrm{C}$ mineralization. Vertical bars represent + S.E.M.

\subsubsection{Nitrogen}

As illustrated in Figure 3 the nitrogen was immobilized in the initial period to about $4.3 \mathrm{mg} \mathrm{N} \mathrm{kg}^{-1}$ of dry soil in $\mathrm{N} 250$ and $8.3 \mathrm{mg} \mathrm{N} \mathrm{kg-}^{-1}$ of dry soil in N0 treatments. While, the N500 treatment was mineralized immediately. The N-net mineralization increased to around $17.8,12.6$ and $8.6 \mathrm{mg} \mathrm{N} \mathrm{kg}^{-1}$ of dry soil after 120 days for the N500, N250 and N0 treatments, respectively. After about 120 this mineralization was essentially complete because the rate of release of $\mathrm{N}$ thereafter was very slow, this is complete agreement with the results of the mineralization of carbon (Figure 2). At day120, the statistical analyzes showed a significant difference between treatments $(p<0.05)$. At the end of the incubation period, the $\mathrm{N}$ - net mineralization of the artichoke 
residues was of 19.1, 14.1 and $10.5 \mathrm{mg} \mathrm{N} \mathrm{kg}^{-1}$ of dry soil for the N500, N250 and N0 treatments, respectively. In this study, the net $\mathrm{N}$ mineralization ranged from
$38.26 \mathrm{mg} \mathrm{N} \mathrm{kg}^{-1}$ dry soil for the control soil without residues to 56.30 (38.26 soil +18.04 residues) $\mathrm{mg} \mathrm{N}$ $\mathrm{kg}^{-1}$ dry soil for the soil treated with residues N500.

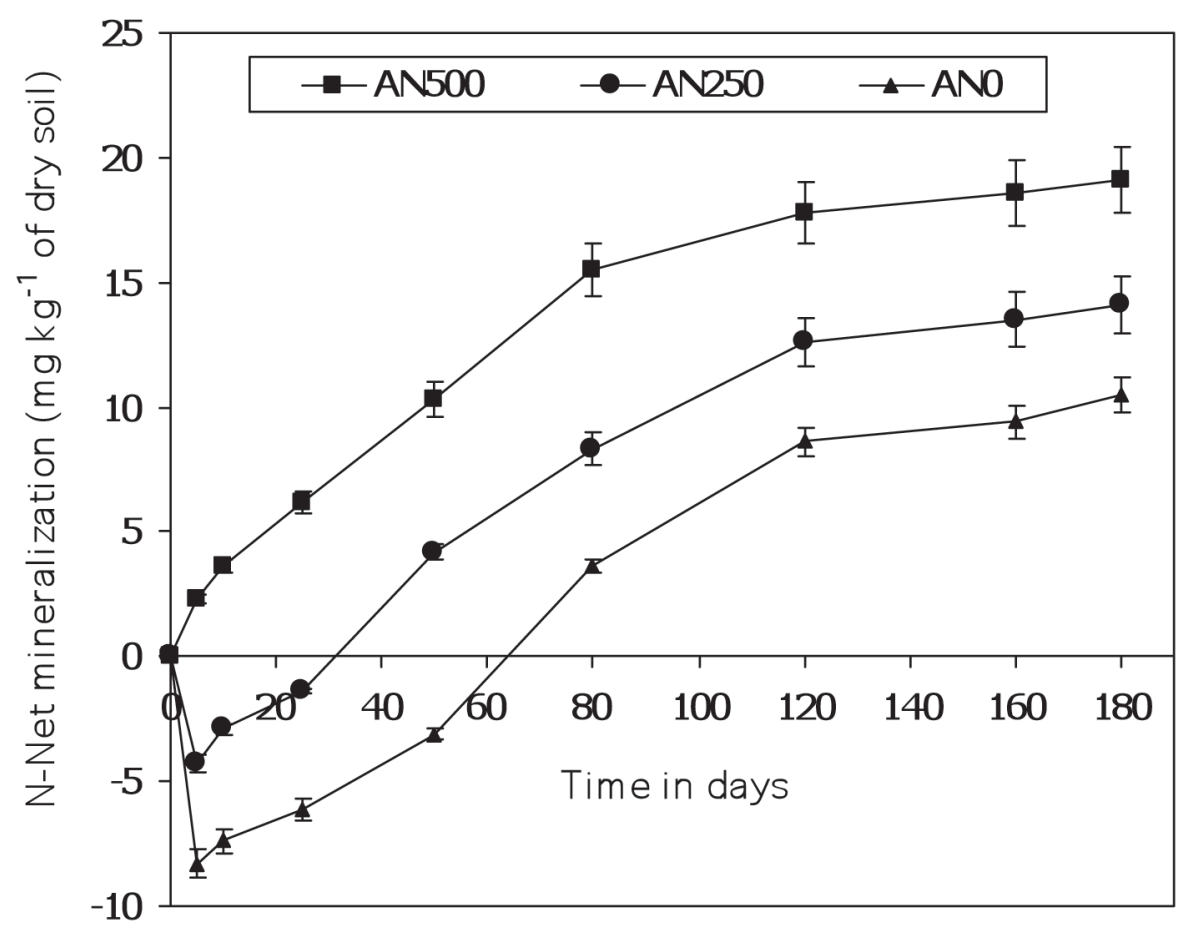

Figure 3. Temporal evolution of the cumulative net $\mathrm{N}$ mineralized of artichokes residues fertilized with the three studied N rates. Vertical bars represent + S.E.M.

\section{Discussion}

\subsection{Effect of nitrogen fertilization on the carbon and nitrogen mineralization}

Carbon of artichoke residues was mineralized about $60 \%$ of total organic carbon after 50 days of incubation. This indicates that the artichoke residues were degraded quickly. Jenkinson (1977); Sauerbeck and Gonzalez (1977) explained that easily organic compounds was degradable in the early phase of decomposition by the micro-organisms and which consti- tute according to these results more than $55 \%$ of the dry matter of the products used. Ajwa and Tabatabai (1994) and Recous (2002) found that the carbon from sugar beet residues mineralizes more quickly in soils, than that from other crop residues, suggesting that the readily decomposable organic $-\mathrm{C}$ fraction in sugar beet residues higher than in other crop residues. The chemical composition of artichoke residues found here were the same pattern as in the sugar beet residues. The carbon mineralization process observed was best described by combined two steps, which suggests that 
the organic carbon content of the residues was made up of two fractions of different degree of biodegradability: labile organic compounds which were rapidly mineralizable in soil, and compounds which were resistant to microbial attack and which broke down slowly during a second step (Bernal et al., 1998). C mineralization was high about $12 \%$ for a mixture cotton (leaves and stems) compared to stems only. These results indicated that carbon mineralization improved with mixed of different plant parts, especially in the components of the mixture that contained a little nitrogen, or molecules of the plant parts limiting the decomposition (Quemada and Cabrera1995).

Net $\mathrm{N}$ immobilization was observed during the first days of incubation in N0 and N250 treatments. The $\mathrm{C}$ : $\mathrm{N}$ ratio of the returned organic matter is known to vary with sampling time, decomposition stage, and quality (Kumar and Goh, 2000), and can thus result in an increased or decreased effect on $\mathrm{N}$ mineralization. Since the ability of soil organisms to break down additional organic substrate does not normally change as a result of system diversity (Sanchez et al., 2001), the $\mathrm{C}: \mathrm{N}$ status of the returned organic matter probably played an important role in increasing or decreasing the effect of previous $\mathrm{N}$ application on $\mathrm{N}$ mineralization. Most authors (e.g., Paul and Clark, 1989) have suggested that net $\mathrm{N}$ mineralization occurs when $\mathrm{C} / \mathrm{N}$ ratios are $>25$. Nevertheless, some authors (e.g., McKenney et al. 1995 and Jensen, 1994) found that the vegetable residues with a low $\mathrm{C}$ : $\mathrm{N}$ ratio can cause net immobilization of the mineral $\mathrm{N}$ soil which it was in agreement with these results. In treatment N500, the micro-organisms were used the first mineral nitrogen of the residues directly that it was available, before using nitrogen resulting from the mineralization of the residues which it was high, contained $\mathrm{NO}_{3}$ and low $\mathrm{C}$ : $\mathrm{N}$ ratio in their parts (Table 1). On the other hand, the immobilization in the N0 and N250 treatments that it was probably the interaction between leaves and stems which it was higher $\mathrm{C}: \mathrm{N}$ ratio and lower $\mathrm{NO}_{3}$ compared to $\mathrm{N} 500$ treatment (Table 1).

Nitrogen mineralized during laboratory incubation also increased with increasing $\mathrm{N}$ application. Rasmussen et al., (1998) showed a similar flat response of nitrogen mineralized increased with increasing $\mathrm{N}$ application. The high $\mathrm{N}$ release from the N500 and N250 compared to N0 indicated that it was due to residual effect of fertilization on the mineralization. $\mathrm{Li}$ et al. (2010) found that the cumulative mineralization of organic $\mathrm{N}$ and $\mathrm{C}$ increased with paddy soil fertility level (high $>$ middle $>$ low). Carpenter et al. (2000) who reported that more $\mathrm{N}$ was mineralized from plots receiving high fertilizer $\mathrm{N}$ than from plots receiving low fertilizer $\mathrm{N}$, and that there was more $\mathrm{N}$ mineralized from plots receiving no fertilizer $\mathrm{N}$.

The net $\mathrm{N}$ mineralization ranged from $38.26 \mathrm{mg}$ $\mathrm{N} \mathrm{kg}^{-1}$ dry soil for the control soil without residues to 56.30 (38.26 soil +18.04 residues) $\mathrm{mg} \mathrm{N} \mathrm{kg}^{-1}$ dry soil for the soil treated with residues N500. The net $\mathrm{N}$ mineralization in this study was different the net $\mathrm{N}$ mineralization of cauliflower residues in the field reported by (De Neve and Hofman, 1998). This may be attributed to the different of plant types, initial total $\mathrm{N}$ content in the soil, experiment application and chemical composition of the type residues.

\section{Conclusions}

Nutrient release from artichoke residues is important to $\mathrm{N}$ management and the success of conservation and sustainable farming systems. Nitrogen immobilized in the initial period with low $\mathrm{C}: \mathrm{N}$ ratio was observed in this study. $\mathrm{C}$ and $\mathrm{N}$ mineralization from artichoke residues was dependent on the initial total $\mathrm{N}$ content in the plant and chemical composition of the artichoke residues. Nitrogen and carbon mineralized during laboratory incubation increased with increasing $\mathrm{N}$ ap- 
plication. Previous $\mathrm{N}$ fertilization for artichoke plants was effect on the chemical composition and $\mathrm{C}$ and $\mathrm{N}$ mineralization of the artichoke residues, these studies could lead to greater efficiency of $\mathrm{N}$ use in crop management rotation systems.

\section{Acknowledgements}

I thank the Laboratory of Soil and Water Sciences, Agriculture faculty, Tanta University, Egypt for assistance during this work.

\section{References}

Ajwa, H.A., Tabatabai, M.A., 1994. Decomposition of different organic materials in soils. Bio. Fert. Soils 18, 3, 175-182.

AFNOR. 1991. Matières fertilisantes et supports de culture, Recueil des normes Françaises. AFNOR, Paris, p. 713.

Alt, C., Kage, H., Stützel, H., 2000. Modelling Nitrogen content and distribution in cauliflower (Brassica oleracea L. botrytis). An. Biota. 86, 963-973.

Azza, A., El-din, E., Eman, E., Aziz, S.F., Hendawy, E., Omer A., 2010. Impact of phosphorus nutrition and number of cuttings on growth, yield and active constituents of artichoke. Inter. J. Acad. Res. 2, 4, 240- 244.

Bernal, M.P., Sanchez- Monedero, M.A., Paredes, C., Roig, A., 1998. Carbon mineralization from organic wastes at different composting stages during their incubation with soil. Agri. Eco. Environ. 69. 175-189.

Bremner, J. M., Mulvaney, C. S., 1982. Nitrogen-Total. In Methods of Soil Analysis, Part 2, Agronomy 9, ed. A. L. Page, R. H. Miller and D. R. Keeney, pp.595-624. American Society of Agronomy, Madison.
Carpenter-boggs, L., Pikul, J.r., Vigil, M. F., Riedell, W. E., 2000. Soil nitrogen mineralization influenced by crop rotation and nitrogen fertilization. Soil Sci. Soc. Am. J. 64, 2038-2 045.

De Neve, S., Hofman, G., 1998. N mineralization and nitrate leaching from vegetable crop residues under field conditions: a model evaluation. Soil Biol. Biochem. 30, 2067-2075.

De Neve, S., Hoffman, G., 2002. Quantifying soil water effects on nitrogen mineralization from soil organic matter and from fresh crop residues. Biol Fertil Soils 35:379-386.

El-Shemy, S., Aly, B., 1997. Report on agriculture wastes in Egypt. (In. El-Galaa A.(ed.) Organic agriculture, 308.

Everaarts, A.P., De Moel, C.P., Van Noordwijk, M., 1996. The effect of nitrogen and the method of application on nitrogen uptake of cauliflower and on nitrogen in crop residues and soil at harvest, Netherlands J. Agri. Sci. 44,1, 43-55.

Islam, K.R., Weil, R.R., 2000. Soil quality indicator properties in mid-Atlantic soils as influenced by conservation management. J. Soil and Water Conserv. 55:69-78.

Jenkinson, D.S., 1977. Studies on the decomposition of plant material in soil. V. The effect of plant cover and soil type on the loss of carbon from 14C-labelled ryegrass decomposing under field conditions. J. Soil Sci. 28, 424-434.

Jensen, E.S., 1994. Dynamics of mature pea residue nitrogen turnover in unplanted soil under field conditions. Soil. Biol. Biochem. 26, 455-464.

Keeney, D. R., Bremner, J. M., 1966. Comparison and evaluation of laboratory methods of obtaining an index of soil nitrogen availability. Agro. J. 58, $498 \pm 503$.

Kumar, K., Goh, K. M., 2000. Crop residues and management practices: Effects on soil quality, 
soil nitrogen dynamics, crop yield, and nitrogen recovery. Adv. Agron. 68, 197-319.

Li, Z.P., Han, C.W., Han, F.X., 2010. Organic C and $\mathrm{N}$ mineralization as affected by dissolved organic matter in paddy soils of subtropical China. Geoderma 157, 206-213.

Lisiewska, Z., Kmiecik, W., 1996. Effects of level of nitrogen fertilizer, processing conditions and period of storage of frozen broccoli and cauliflower on vitamin $\mathrm{C}$ retention. Food Chemistry 57,2, 267-270.

McKenney, D.J., Wang S.W., Drury, C.F. Findlay, W.I., 1995. Denitrification and mineralization in nitrate limited and no limited residue-amended soil. Soil Sci.Soc. Am. J. 59, 118-124.

Page, A.L., 1982. Methods of Soil Analysis. Part. 2 Chemical and microbiological properties (2nd ed.), Amer. Soc. Agron. Inc. Soil Sci. Soc. Amer. Inc. Madison. Wisconsin U.S.A.

Paul, E.A., Clark, F.E., 1989. Soil microbiology and biochemistry. Academic Press, Orland, Florida, USA.

Qualls, R.G., Richardson C.J., 2000. P enrichment affects litter decomposition, immobilization, and soil microbial P in wetland mesocosms. Soil Sci. Soc. Am. J. 64,799-808.

Quemada, M., Cabrera.M.L., 1995. Carbon and nitrogen mineralization from leaves and stems off furnaces cover crops. Soil Sci. J. 59,471 - 477.

Rahn, C.R., Lilly, R., 2002. A study of the quality factors affecting the short term decomposition of field vegetable residues. J. Sci. Fo. Agri. 82, 1926.

Rahn, C.R., Vaidyanathan, L.V., Paterson, C.D., 1992. Nitrogen residues from brassica crops. Aspect App. Bio. 30, 263-270.
Rasmussen, P. E., Douglas, J.r., Collins, H. P., Albrecht, S. L., 1998. Long-term cropping system effects on mineralizable nitrogen in soil. Soil Biol. Biochem. 30: 1829-1 837.

Recous, S., Luxhøi, j., Fillery, I. P., Jensen, L.S., Mary, B., 2002. Use of $15 \mathrm{~N}$ dilution to study effects of soil temperature on $\mathrm{N}$ mineralisation, immobilisation and nitrification. At:17 th soil science world conference, Bangkok, Thailand.

SAS Institutes, 1996. SAS/Stat User's Guide.Version 6.4th ed. SAS Institute Inc., Cary. NC.

Sauerbeck, D.R., Gonzalez, M.A., 1977. Field decomposition of carbon-14-labelled plant residues in various soils of the Federal Republic of Germany and Costa Rica. In: Soil Organic Matter Studies Vol. I, International Atomic Energy Agency, Vienna. 159-170.

Sanchez, J. E., Willson, T. C., Kizilkaya, K., Parker, E., Harwood, R. R., 2001. Enhancing the mineralizable nitrogen pool through substrate diversity in long term cropping systems. Soil Sci. Soc. Am. J. 65, 1442-1 447.

Van Soest, P.J., 1963. Use of detergents in the analysis of fibrous feeds. II. A rapid method for the determination of fiber and lignin. J. Assoc. Off. Anal. Chem. 46, 829-835.

Wehrmann, J., Scharpf, H.C., 1989. Reduction of nitrate leaching in a vegetable farm: fertilization, crop rotation, plant residues in Management systems to reduce impact of nitrates, Germon, J.C.Dupain, S. (eds.). - New York (USA): Elsevier Applied Science, 18-516-64025. p. 147-15.

Zhu, J.H., Li, X.L., Christie, Li, J.L., 2005. Environmental implications of low nitrogen use efficiency in excessively fertilized hot pepper (Capsicum frutescens L.) cropping systems. Agri. Eco. Environ. $111,70-80$. 
